\title{
Pendidikan Kesehatan tentang Anemia pada Remaja Putri di SMA N 12 Kabupaten Merangin
}

\author{
Dini Junita ${ }^{1}$, Arnati Wulansari ${ }^{2}$ \\ ${ }^{1,2}$ Program Studi Ilmu Gizi, STIKes Baiturrahim Jambi \\ Email: dinijunita.dj.dj@gmail.com
}

Submitted : 25/11/2020

Accepted: 09/12/2020

Published: 11/01/2021

\begin{abstract}
Anemia is the impact of nutritional problems on teenager girl. Nutritional anemia is caused by a lack of nutrients that play a role in the formation of hemoglobin, it can be due to lack of consumption or absorption disorders. Only $62 \%$ of anemia mothers have received iron supplemented tablets in the working area of Puskesmas Simpang Limbur, while the iron supplemented tablet program for teenager girls in high school has not been implemented. The purpose of this community service activity is to provide information and motivation to teenagers to prevent anemia. Providing information in the form of health education regarding the definition, signs, clinical signs and symptoms and the impact of anemia. The implementation method is in the form of counseling, discussion, practice simulation and pre-post test evaluation. Monitoring evaluation is carried out by looking at the indicators of success in the aspect of target attendance attending every meeting in service and practice activities to the target, reflections and feedback from the participants. The results of the activity show that school support is very good, students' knowledge of anemia is more than $80 \%$. The material still needs to be improved regarding the risk factors for anemia in adolescents. Collaboration with health workers is needed to gain new knowledge on a regular basis, as well as empowering students as youth cadres.
\end{abstract}

Keywords: anemia, education, iron, supplements, teenager

\begin{abstract}
Abstrak
Anemia merupakan dampak masalah gizi pada remaja putri. Anemia gizi disebabkan oleh kekurangan zat gizi yang berperan dalam pembentukan hemoglobin, dapat karena kekurangan konsumsi atau gangguan absorbsi. Cakupan pemberian tablet tambah darah di wilayah kerja Puskesmas Simpang Limbur baru tercapai sekitar 62\% ibu anemia yang mendapat tablet tambah darah sedangkan program tablet tambah darah bagi remaja putri di SMA belum terlaksana. Tujuan kegiatan pengabdian masyarkat ini pemberian informasi dan motivasi kepada remaja putri untuk cegah anemia. Pemberian informasi berupa penyuluhan kesehatan mengenai pengertian, tanda, tanda dan gejala klinis dan dampak dari anemia. Metode pelaksanaan berupa penyuluhan, diskusi, simulasi praktek dan evaluasi pre-post tes. Monitoring evaluasi dilakukan dengan melihat Indikator keberhasilan pada aspek kehadiran sasaran menghadiri setiap pertemuan pada kegiatan pengabdian dan praktik kepada sasaran, refleksi dan umpan balik dari peserta Hasil kegiatan diketahui dukungan sekolah sangat baik, pengetahuan siswi tentang anemia lebih dari $80 \%$. Materi yang masih perlu dtingkatkan mengenai factor resiko anemia pada remaja. Diperlukan kerjasama dengan tenaga kesehatan untuk mendapat ilmu baru secara rutin, serta pemberdayaan siswa sebagai kader remaja
\end{abstract}

Kata kunci : anemia, edukasi, remaja, tablet tambah darah, zat besi 


\section{PENDAHULUAN}

$\begin{array}{ccc}\text { Masa } & \text { remaja } & \text { adalah } \\ \text { perkembangan } & \text { yang } & \text { dinamis } \\ \text { dalam }\end{array}$ kehidupan seseorang individu. Masa ini merupakan periode transisi dari masa anakanak ke masa dewasa yang ditandai dengan percepatan perkembangan fisik, mental emosional dan sosial yang langsung pada dekade kedua masa kehidupan (Pardede 2008). Pada masa tersebut remaja ingin mencari identitas dirinya dan lepas dari keterganungan dengan orangtua nya, menuju pribadi yang mandiri (Gunarsa 2006). Proses penetapan identitas diri ini tidak selalu berjalan mulus, tetapi sering bergejolak, oleh karena itu, banyak ahli menamakan periode ini sebagai masa-masa strom and stress (Irwanto 2002). Suatu masa dimana ketegangan emosi meninggi sebagai akibat dari perubahan fisik dan kelenjar. Remaja mudah terkena pengaruh dari lingkungan termasuk pola makan, dengan mengikuti diet demi menjaga body image (Gunarsa, 2006). Dampaknya banyak masalah gizi muncul pada kelompok usia ini, khususnya bagi remaja putri.

Salah satu masalah yang sering muncul pada remaja putri adalah anemia. Anemia merupakan dampak masalah gizi pada remaja putri. Anemia gizi disebabkan oleh kekurangan zat gizi yang berperan dalam pembentukan hemoglobin, dapat karena kekurangan konsumsi atau gangguan absorbsi. Zat gizi tersebut adalah besi, protein vitamin B6 yang berperan sebagai katalisator dalam sintesis hemoglobin dalam molekul hemoglobin, vitamin $\mathrm{C}$, zat zinc yang mempengaruhi absorbsi besi dan vitamin $\mathrm{E}$ yang mempengaruhi stabilitas membran sel dalam darah. Sebagian besar adalah anemia gizi besi. Penyebab anemia gizi besi adalah kurangnya asupan besi, terutama dalam bentuk besi-hem (Alamatsier, 2009). Menurut Riset Kesehatan Dasar tahun 2013 prevalensi anemia di Indonesia sebesar 21,7\%. Prevalensi anemia pada wanita di Indonesia sebesar 23,9\%. Sedangkan prevalensi anemia pada wanita umur 5-14 tahun sebesar 26,4\% dan umur 15-25 tahun sebesar $18,4 \%$.

Kekurangan zat besi akan menyebabkan terjadinya penurunan kadar feritin yang diikuti dengan penurunan kejenuhan transferin atau peningkatan protoporfirin. Keadaan yang harus terus berlanjut akan menyebabkan anemia defisiensi besi, dimana kadar hemoglobin turun dibawah nilai normal (Almatsier, 2009). Menurut penelitian yang dilakukan Tadete dkk (2012) rendahnya tingkat penyerapan zat besi didalam tubuh merupakan kesulitan utama untuk memenuhi kebutuhan zat besi terutama sumber zat besi dari nabati yang diserap 1$2 \%$. Kebiasaan mengkonsumsi makanan yang dapat mengganggu penyerapan zat besi (seperti kopi dan teh) secara bersamaan pada waktu makan menyebabkan penyerapan zat besi semakin rendah.

Konsumsi makan berkaitan erat dengan status gizi. Remaja yang memiliki status gizi kurang akan berisiko terkena anemia terutama pada remaja putri. Anemia juga dipengaruhi secara langsung oleh konsumsi makanan sehari-hari yang kurang mengandung zat besi. Pada remaja putri, kebutuhan besi tambahan diperlukan untuk menyeimbangkan kehilangan zat besi akibat darah haid, sehingga terjadi peningkatan kebutuhan besi untuk mengganti kehilangan darah total (Hapzah, 2012).

Berdasarkan laporan dinkes Kabupaten Merangin dalam tahun 2018 diketahui bahwa permassalah anemia khususnya pada ibu hamil masih cukup tinggi. Sedangkan cakupan pemberian tablet tambah darah belum merata, untuk wilayah kerja Puskesmas Simpang Limbur baru tercapai sekitar $62 \%$ ibu anemia yang mendapat tablet tambah darah sedangkan program tablet tambah darah bagi remaja putri di SMA belum terlaksana. Padahal diketahui bahwa remaja putri merupakan kelompok usia subur dan calon ibu yang penting untuk mempersiapkan status gizi 
termasuk terhindar dari anemia. Permasalahan ini melatarbelakangi perlunya penyuluhan terhadap remaja putri di lokasi mengenai penanggulangan anemia. SMA N 12 Merangin adalah salah satu SMA yang terletak di Desa Simpang Limbur dengan jumlah siswi sebanyak 560 orang. Lokasi ini strategis untuk dilakukan penyuluhan tentang Anemia Pada Remaja Puteri.

\section{TARGET DAN LUARAN}

Kegiatan pengabdian ini memberikan solusi terkait masalah tingginya kejadian anemia pada Wanita Usia Subur di wilayah kerja Simpang Limbur Meragin berupa:

1. Pemberian informasi berupa penyuluhan kesehatan mengenai pengertian, tanda, tanda dan gejala klinis dan dampak dari anemia

2. Pemberian informasi tentang cara menanggulangi anemia dalam pengaturan pola makan bergizi, berimbang, beragam.

3. Memotivasi remaja agar selalu aktif dalam menimbang dan memantau status gizi dan peduli terhadap teman sebaya dengan tanda dan gejala anemia.

4. Memberikan informasi tata laksana gizi, penanggulangan dan rujukan yang tersedia di pelayanan kesehatan dasar bagi remaja dengan masalah gizi,

Kegiatan pengabdian ini memiliki target khusus yaitu menghasilkan media leaflet dan poster tanda gejala anemia, poster pirim makanku untuk remaja, serta luaran publikasi karya tulis ilmiah dan bahan ajar pada mata kuliah pendidikan gizi dan kesehatan.

\section{METODE PELAKSANAAN}

Kegiatan ini telah dilaksanakan pada dilaksanakan selama 6 bulan pada bulan Februari 2018 s/d Agustus 2019 berlokasi di SMA N 12 Kec. Pamenang Barat wilayah kerja Puskesmas Simpang Limbur Kabupaten Merangin. yaitu:

Tujuan dari kegiatan pengabdian ini

1) Menciptakan leaflet dan modul yang efektif dalam menyampaikan pesan cara mengenali tanda gejala anemia dan bagaimana cara untuk memberi makan yang tepat agar remaja terhindar dari anemia.

2) Remaja dapat meneruskan informasi yang diperoleh kepada teman sebaya.

Sasaran penyuluhan yang akan dilaksanakan yaitu remaja putri yang merupakan siswi SMA N 12 Kab. Merangin, perwakilan dari kelas X,XI,dan XII. Adapun kontribusi sasaran dalam pengabdian masyarakat ini adalah:

1) Menjadi peserta kegiatan pengabdian

2) Mengikuti pre dan post test

3) Aktif dalam bertanya serta menjawab dan mempraktekkan saat simulasi

\section{Tahap Kegiatan}

Tahapan pelaksanaan kegiatan pengabdian kepada masyarakat ini adalah sebagai berikut:

\section{Persiapan}

a) Menyusun proposal kegiatan pengabdian kepada masyarakat.

b) Menyiapkan poster dan leaflet

c) Menyiapkan materi presentasi

d) Menyiapkan lembar pre-test dan post test tentang pengetahuan terkait deteksi anemia dan pola makan yang dapat menghindarkan remaja dari anemia.

\section{Pelaksanaan Kegiatan}

a) Perkenalan antara tim pengabdian kepada masyarakat dengan sasaran

b) Penjelasan kegiatan yang akan dilakukan dalam melibatkan sasaran

c) Memberikan lembar pre-test

d) Melaksanakan penyampaian pesan melalui media poster dan leafleat.

e) Memberikan stimulasi dan motivasi agar remaja agar selalu aktif dalam menimbang dan memantau status gizi dan peduli terhadap teman sebaya dengan tanda dan gejala anemia.

f) Memberikan lembar post-test 
g) Penutupan

\section{Monitoring dan Evaluasi}

Monitoring dan evaluasi (Monev) dilakukan dengan teknik wawancara dan observasi langsung kepada sasaran. Cakupan Monev dalam kegiatan ini meliputi empat aspsek, yaitu sebagai berikut:

\section{1) Monev Perencanaan}

Pada aspek ini tim akan mengevaluasi kondisi mitra, tujuan program, permasalahan dan pemacahan masalah mitra, isi materi dan praktik kegiatan, media/ alat yang digunakan, sasaran dalam kegiatan pengabdian, waktu pelaksanaan evaluasi (berapa lama, dan kapan evaluasi dilaksanakan), sarana dan prasaran, dan dana yang digunakan.

2) Monev Pelaksanaan Kegiatan

Indikator keberhasilan pada aspek ini adalah:

a. Sebanyak 90-100\% sasaran menghadiri setiap pertemuan pada kegiatan pengabdian.

b. Kemampuan tim dalam menyampaikan materi dan praktik kepada sasaran.

c. Refleksi dan umpan balik dari peserta kegiatan.

\section{HASIL DAN PEMBAHASAN}

1. Gambaran Umum Lokasi Pengabdian

SMAN 12 Merangin terletak di Jalan Majapahit Desa Pinang Merah Kecamatan Pamenang Barat, Kabupaten Merangin. Di bidang kesehatan khususnya, SMA Negeri 12 Merangin pernah mendapat banyak prestasi antara lain Juara 5 Lomba sekolah sehat tingkat nasional tahun 2010 (tingkat SMA/MAN/SMK ), Juara 1 pennyuluhan kader UKS tingkat provinsi (2013), Finalis lomba artikel tingkat Provinsi (2013), serta berhasil merebut juara kedua program Usaha Kesehatan Sekolah (UKS)
Tingkat Nasional setelah SMA Negeri Bantul Jawa Tengah.

2. Pelaksanaan Kegiatan

Sasaran dalam kegiatan ini adalah Remaja Putri, 150 siswi dari kelas X, XI dan XII yang hadir dalam kegiatan. Namun untuk mendapatkan gambaran pengetahuan terkait materi dilakukan pre-post test pada 33 sampel yang diambil secara acak.

Sebelum diberikan materi anemia gizi besi dan penatalaksanaannya, remaja diberikan soal pre-test untuk mengukur pengetahuan awal sebelum diberikan penyuluhan. Setelah dilakukan penyuluhan, sasaran diberikan soal post-test untuk mengukur pengetahuan sasaran setelah diberikan penyuluhan. Selain itu, pada pelaksanaan tim pengabdian juga mempraktikkan cara mengidentifikasi ciri atau tanda anemia pada remaja.
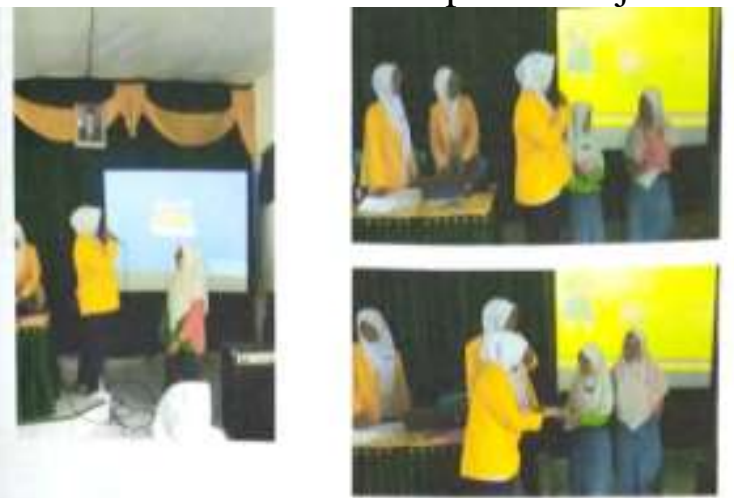

Gambar 1. Pemberian materi dan tanya jawab

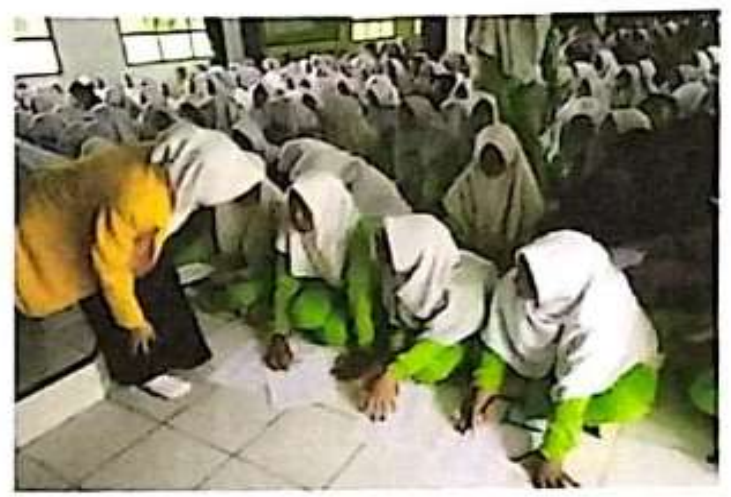

Gambar 2. Pengisian kuisioner 
3. Hasil Kegiatan

Dari seluruh kegiatan implementasi yang telah dilaksanakan, kegiatan tersebut berjalan sangat baik. Siswi-siswi SMAN 12 merangin antusias mulai dari penyampaian materi iku serta menyimak dengan baik, pemberian pretest dan post-test, dilanjutkan dengan sesi tanya jawab dan pemberian hadiah bagi siswi yang aktif dalam kegiatan.

Pengetahuan tentang anemia yang ingin diketahui dari siswi diramu dalam bentuk kuisioner yang terdiri dari 10 pertanyaan mengenai definisi anemia, tanda dan gejala, penyebab, dampak, cara menanggulangi dan asupan gizi terkait anemia gizi besi. Berdasarkan hasil rekapitulasi kuisioner pre post test mengenai anemia diketahui pengetahuan siswi SMA N 12 Merangin mengalami peningkatan rata-rata sebesar 10-15\%, dari rata-rata nilai 83 menjadi 95 . Rincian jawaban tiap pertanyaan dapat dilihat pada table 1 .

Tabel 1 Distribusi Frekuensi Responden Berdasarkan Jawaban Pertanyaan Pre test dan Post test pengetahuan anemia

\begin{tabular}{|c|c|c|c|c|c|c|c|c|c|}
\hline \multirow{3}{*}{ No } & \multirow{3}{*}{ Pertanyaan } & \multicolumn{4}{|c|}{ Pre-test } & \multicolumn{4}{|c|}{ Post-test } \\
\hline & & \multicolumn{2}{|c|}{ Benar } & \multicolumn{2}{|c|}{ Salah } & \multicolumn{2}{|c|}{ Benar } & \multicolumn{2}{|c|}{ Salah } \\
\hline & & $\mathrm{n}$ & $\%$ & $\mathrm{n}$ & $\%$ & $\mathrm{n}$ & $\%$ & $\mathrm{n}$ & $\%$ \\
\hline 1 & Pengertian anemia & 30 & 91 & 3 & 9 & 33 & 100 & 0 & 0 \\
\hline 2 & Suplemen cegah anemia & 27 & 82 & 6 & 18 & 33 & 100 & 0 & 0 \\
\hline 3 & Faktor resiko anemia & 33 & 100 & 0 & 0 & 31 & 94 & 2 & 6 \\
\hline 4 & Tanda dan gejala anemia & 32 & 97 & 1 & 3 & 33 & 100 & 0 & 0 \\
\hline 5 & Penyebab anemia & 33 & 100 & 0 & 0 & 33 & 100 & 0 & 0 \\
\hline 6 & Dampak anemia & 33 & 100 & 0 & 0 & 33 & 100 & 0 & 0 \\
\hline 7 & Penanggulangan anemia & 23 & $\mathbf{7 0}$ & 10 & 30 & 30 & 91 & 3 & 9 \\
\hline 8 & Sumber gizi besi & 15 & 45 & 18 & 55 & 32 & 97 & 1 & 3 \\
\hline 9 & Factor resiko perempuan & 32 & 97 & 1 & 3 & 33 & 100 & 0 & 0 \\
\hline 10 & Faktor resiko lain & 19 & 58 & 14 & 42 & 21 & 64 & 12 & 36 \\
\hline
\end{tabular}

Berdasarkan sebaran jawaban diketahui bahwa pertanyaan paling banyak dijawab salah saat pre test adalah mengenai sumber gizi besi sebanyak 18 orang (55\%) salah menjawab dan factor resiko anemia sebnyak 14 orang $(42 \%)$ salah menjawab. Setelah dilakukan pemberian materi dan pemahaman terjadi penurunan tingkat kesalahan menjadi 1 orang $(3 \%)$ pada pertanyaan sumber gizi besi dan 12 orang $(36 \%)$ pada factor resiko lain.

Dari seluruh kegiatan implementasi yang telah dilaksanakan dapat disimpulkan bahwa $100 \%$ sasaran menghadiri setiap pertemuan pada kegiatan pengabdian. Respon dan umpan balik dari peserta sangat baik, peserta aktif bertanya dan menjawab. Hasil pre post tes menunjukkan bahwa pengetahuan

\section{KESIMPULAN DAN SARAN}

\section{Kesimpulan}

Berdasarkan hasil kegiatan pengabdian ini diketahui kelompok sasaran memiliki pengetahuan tentang anemia yang baik. Namun pengetahuan awal tes masih banyak peserta menjawab salah pada pertanyaan mengenai penanggulangan anemia, sumber zat besi serta faktor resiko lain penyebab anemia pada wanita.

\section{Saran}

Meskipun pengetahuan remaja dalam kegiatan ini sudah cukup baik, tetap diperlukan pengawasan dan pendidikan kesehatan dengan sistem berkelanjutan 
melalui UKS. Serta kedepannnya dapat dilakukan pemberdayaan siswa SMA untuk menjadi kader penanggulangan anemia remaja di lingkungannya.

\section{UCAPAN TERIMAKASIH}

Pengabdi mengucapkan terimakasih kepada STIKes Baiturrahim Jambi atas dukungan moril serta materi yang bersumber dari dana pengabdian internal STIKBA sehingga kegiatan ini dapat terlaksana dengan baik.

\section{DAFTAR PUSTAKA}

Budioro B. 2002. Pengantar pendidikan penyuluhan kesehatan masyarakat. Semarang: Fakultas Kesehatan Masyarakat Universitas Diponegoro. ISBN: 9799156041.

Briawan D. Anemia: Masalah Gizi pada Remaja Wanita. Jakarta: EGC.

Cendani ,C \& Murbawani, EA., 2011. Asupan Mikronutrien Kadar Hemoglobin dan Kesegaran Jasmani Remaja Putri, Program Studi Ilmu Gizi. Fakultas Kedokteran Universitas Diponegoro. pp. 26-33.

Citrakesumasari. 2012. Anemia Gizi, Masalah dan Pencegahannya Cet. 1 Yogyakarta: Kalika.

Dewi, RC., 2008. Pengaruh Suplementasi Tablet Tambah Darah (TTD). Seng, dan Vitamin A Terhadap Kadar Hemoglobin Ibu Hamil.pp. 13-19.

Dewoolkar, A, Patel, ND \& Dodich, C., 2014.Iron deficiency and Iron Deficiency Anemia in Adolescent Athletes: A Systematic Review.Int J Child Health Hum Dev . pp. 11-19

Han. 2015. SMA N 12 Merangin Juara Dua UKS Nasional. Berita online focus Jambi. Dapat diakses pada : https://fokusjambi.com/post/detail/sman-12-merangin-juara-dua-uksnasional.html. 